\title{
Investigation of livestock and fishery product supply status to central market : Focus on Southern Ethiopia with perspectives and future opportunities
}

\author{
TEKLU GEBRETSADIK WANA ANDAMAREARGAW
}

\begin{abstract}
Marketing is the answer to the under development of developing countries. Despite the past six years data shows an accelerated increase of livestock and fish supply, the huge livestock resource base in Ethiopia, particularly Southern region did not fully harvested its out puts as its high livestock and resource potential. Yet, this resource base has incredible potential to contribute to income generation, employment creation, food security and nutrition, social security and poverty reduction. When adopted and practiced, marketing will help to develop appropriate technologies as developing nations provide for the needs of the people and enhance their standard of living, create job opportunities, wealth for entrepreneurs, a means towards affording education and enjoyment of leisure. Since the livelihood of smallholders is highly dependent on the cash income from livestock and livestock products, alleviating constraints to production, the export market and domestic trade and marketing structure, improving market information, and upgrading marketing infrastructures including health and sanitary conditions will increase the welfare of smallholder producers, urban consumers and improve the national balance of payments.
\end{abstract}

KEY WORDS : Livestock marketing, Supply economics, Food security, Export trade, Southern Ethiopia

HOW TO CITE THIS PAPER : Wana, Teklu Gebretsadik and Argaw, Amare (2016).Investigation of livestock and fishery product supply status to central market : Focus on Southern Ethiopia with perspectives and future opportunities. Res. J. Animal Hus. \& Dairy Sci., 7(2) : 96103 : DOI: 10.15740/HAS/RJAHDS/7.2/96-103. 